\title{
Protein $\mathrm{C}$ activation peptide inhibits the expression of ICAM-1, VCAM-1, and interleukin-8 induced by TNF- $\alpha$ in human dermal microvascular endothelial cells
}

\author{
María Del Socorro Pina-Canseco ${ }^{1}$, Araceli Páez-Arenas ${ }^{2}$, Felipe Massó², \\ Eduardo Pérez-Campos ${ }^{3,4}$, Ruth Martínez-Cruz ${ }^{1,4}$, Pedro Hernández-Cruz 1, 4 , \\ Abraham Majluf-Cruz ${ }^{5}$, Margarito Martínez-Cruz ${ }^{3}$, Laura Pérez-Campos Mayoral ${ }^{4}$, \\ Alma Dolores Pérez-Santiago ${ }^{3}$, Edgar Zenteno ${ }^{4,6}$
}

${ }^{1}$ CICIMEBIO. Faculty of Medicine and Surgery of Universidad Autónoma Benito Juárez Oaxaca (UABJO), Oaxaca, Mexico

${ }^{2}$ National Institute of Cardiology, Ignacio Chavez, Mexico City, Mexico

${ }^{3}$ Biochemistry and Immunology Unit of the Technological Institute of Oaxaca

- Universidad Nacional Autónoma de México (ITO-UNAM), Oaxaca, Mexico

${ }^{4}$ Institute of Multidisciplinary Investigation, UNAM - UABJO, Oaxaca, Mexico

${ }^{5}$ Medical Investigation Unit on Thrombosis, Hemostasis and Atherogenesis, Instituto Mexicano del Seguro Social (IMSS), México

${ }^{6}$ Laboratory of Immunology, Department of Biochemistry, Faculty of Medicine, UNAM, Mexico City, Mexico

\begin{abstract}
Activated protein C (APC) is generated from the cleavage of protein C by thrombin coupled to thrombomodulin and, subsequently, is released as protein $\mathrm{C}$ activation peptide (papC). The aim of this study was to evaluate the effect of papC on human dermal microvascular endothelial cells (HMEC-1), activated with $5 \mathrm{ng}$ / $/ \mathrm{mL}$ TNF- $\alpha$. Flow cytometry showed that papC inhibited the expression of VCAM-1 and ICAM-1, after activation with TNF- $\alpha$. Similarly, RT-PCR analysis revealed that 2 and $4 \mathrm{pM}$ papC inhibited the expression of VCAM-1 and IL- 8 mRNA in TNF- $\alpha$-treated HMEC-1. In addition, the expression of endothelial nitric oxide synthase (eNOS) increased in HMEC-1 treated with papC, compared to those without treatment. Furthermore, Jurkat cell adhesion to HMEC-1 induced by TNF- $\alpha$ was significantly inhibited after the addition of papC, compared to HMEC-1 without papC $(p=0.03)$. Finally, a control peptide analog to papC showed no effect on the expression of ICAM and VCAM on the surface of HMEC-1. In conclusion, our results suggest that papC exerts antiinflammatory effects on endothelial cells. (Folia Histochemica et Cytobiologica 2012, Vol. 50, No. 3, 407-413)
\end{abstract}

Key words: HMEC-1, VCAM-1, ICAM-1, IL-8, activated protein C

Correspondence address: E. Zenteno, Immunology Laboratory, Biochemistry Department, Faculty of Medicine,

Universidad Nacional Autónoma de México (UNAM),

PO Box 70159, 04510, Mexico;

tel./fax: + 525556232175 ;

e-mail: ezenteno@unam.mx

\section{Introduction}

Activated protein C (APC) is generated physiologically on the endothelial cell surface due to the effect of thrombin coupled to thrombomodulin [1]. Thrombin activates APC by cleavage between arginine-169 
and serine- 170 with the subsequent release of the protein $\mathrm{C}$ activation peptide (papC), a 12-amino acid peptide. The papC inhibits platelet aggregation in the presence of epinephrine and thrombin [2]. APC possesses antihemostatic and antithrombotic effects and participates in inflammation and apoptotic processes [3-5]. Furthermore, protein $\mathrm{C}$ has anti-inflammatory effects [5-7] and has been approved by the Federal Drug Administration (USA) in severe sepsis therapy [8]. APC inhibits the release of inflammatory cytokines such as tumor necrosis factor-alpha (TNF- $\alpha$ ), IL-6, and IL-8 in experimental endotoxin-induced inflammation [9]. Moreover, APC also limits leukocyte adhesion to the endothelium and invasion into adjacent tissues [10]. In an endothelial cell-based system, APC inhibits a variety of inflammatory events in human umbilical vascular endothelial cells, such as cell adhesion molecule expression, cytokine production, and necrosis factor $-\kappa \mathrm{B}(\mathrm{NF}-\kappa \mathrm{B})$ nuclear translocation $[3,8]$; however, as of now, the specific role of papC in the inflammatory process has not been evaluated.

Intercellular adhesion molecule 1 (ICAM-1) is expressed at low concentrations on the membrane of lymphocytes, monocytes, activated eosinophils, and endothelial cells found in the microvasculature, but not in large arteries or veins. ICAM-1 interacts with leukocyte function-associated antigen-1 (LFA-1, CD11a/CD18) and Mac-1 (CD11b), which are members of the $\beta_{2}$-integrin family. The main functions of ICAM-1 are adhesion and trans-endothelial migration of leukocytes [11]; and it participates in T cell activation [12]. The vascular cell adhesion molecule 1 (VCAM-1) is normally expressed by stimulated endothelial cells; it participates in leukocyte adhesion to endothelial cells and in signal pathways [13], and it is expressed on the surface of human umbilical vein endothelial cells (HUVEC).

TNF induces distinct gene expression programs in microvascular and macrovascular human endothelial cells [14]. Endothelial nitric oxide synthase (eNOS) generates nitric oxide, an agent with chemotactic and vessel-dilatatory effects during wound repair. It also regulates collagen deposits, enhances angiogenesis, and regulates chemo-attractant cytokines. IL-8 is a chemo-attractant and an activator of neutrophils, T cells, and other cells of the immune system, and it is regulated by nitric oxide [15]. APC protects the endothelium by suppressing the inflammatory process [16]. In addition, APC diminishes the activation of leukocytes by suppressing E-selectin, ICAM-1, VCAM-1, and the chemokine (C-X3-C motif) ligand 1 or fractalkine $[15,17]$. In this paper, we show that papC inhibits the synthesis and expression of ICAM-1, VCAM-1, and IL-8, while increasing eNOS synthesis in HMEC-1 stimulated with TNF- $\alpha$; moreover, papC inhibits the Jurkat cell adhesion to HMEC-1 induced by TNF- $\alpha$, suggesting that papC has a potential role in inflammation.

\section{Material and methods}

papC and control peptides. The papC peptide $\left(\mathrm{NH}_{2}-\mathrm{DT}\right.$ EDQEDQVDPR-COOH) and the control peptide $\left(\mathrm{NH}_{2}\right.$-ETEDQEDQVDPH-COOH) were obtained from Invitrogen (St. Louis, MO, USA). Both peptides were custom-synthesized for the authors. The control peptide was designed by changing the terminal amino acids of papC, taking into consideration the criteria for amino acid substitutions by solvent exposure [18], and within nonaqueous environments [19]. The papC and the synthetic peptides used as control were $95.4 \%$ pure by HPLC. For the biological assays, both peptides were dissolved in doubly-distilled water.

Cell culture. The endothelial cell line human dermal microvascular endothelial cells, HMEC-1, with a PBR-322based plasmid containing the coding region for the simian virus 40 A gene product, was obtained from the National Institute of Cardiology Ignacio Chavez (Mexico) and culture in $7 \% \mathrm{CO}_{2}$ at $37^{\circ} \mathrm{C}$ in MCDB-131 medium (GIBCO Laboratories, Fairfield, NJ, USA), supplemented with $15 \%$ bovine fetal serum (Hyclone, Erembodegem-Belgium, Perbio Science Europe), $10 \mathrm{mM}$ L-glutamine, $10 \mathrm{ng} / \mathrm{mL}$ endothelial growth factor (EGF, Boehringer, Mannheim, Germany), and $1 \mu \mathrm{g} / \mathrm{mL}$ water-soluble hydrocortisone (Sigma-Aldrich, USA). Cells were harvested every third day in a solution containing $0.25 \%$ trypsin and 1 mM EDTA.

\section{HMEC-1 activation and evaluation of ICAM-1 and VCAM-1} expression. HMEC-1 (200,000 cells/well) in six-well plates (Costar, Cambridge, MA, USA) were stimulated with $5 \mathrm{ng} /$ /mL TNF- $\alpha$ (DakoCytomation, Glostrup, Denmark) as an optimal dose for $6 \mathrm{~h}, 12 \mathrm{~h}$, and $20 \mathrm{~h}$. Experiments were performed using $5 \mathrm{ng} / \mathrm{mL} \mathrm{TNF}$ - $\alpha$, simultaneously incubated in the presence of either papC or the control peptide at $2 \mathrm{pM}$, $4 \mathrm{pM}$, or $6 \mathrm{pM}$, and the results were evaluated after $6 \mathrm{~h}, 12 \mathrm{~h}$, and $20 \mathrm{~h}$. These experiments were performed ten times. To evaluate the expression of ICAM-1 or VCAM- 1 after exposure to TNF- $\alpha$ in the presence of papC or control peptide, the cells were detached with a solution of $0.25 \%$ trypsin and $1 \mathrm{mM}$ Na-EDTA in PBS, washed with PBS, centrifuged at $200 \mathrm{~g}$, and treated with $5 \%$ formalin in PBS for $5 \mathrm{~min}$ at $20^{\circ} \mathrm{C}$. Then, the cells were washed in ice-cold PBS by centrifugation $\left(8 \mathrm{~min}\right.$ at $\left.4^{\circ} \mathrm{C}\right)$, and suspended in $2 \mathrm{~mL}$ of PBS containing either $1 \mu \mathrm{g} / 100 \mu \mathrm{L}$ phycoerythrin (PE)-conjugated mouse monoclonal anti-human VCAM-1/CD106 (FAB5649P, R\&D Systems, Minneapolis, MN, USA) or mouse anti-human ICAM-1 FITC conjugated monoclonal antibody (CBL450F, Millipore Corporation, USA). After incubation for $1 \mathrm{~h}$ at $20^{\circ} \mathrm{C}$, the cells were washed with icecold $1 \%$ BSA-PBS to remove the unbound antibody. The 
cell pellet was recovered by centrifugation $(200 \mathrm{~g}, 8 \mathrm{~min}$, at $4^{\circ} \mathrm{C}$ ) and resuspended in $1 \mathrm{~mL}$ of cold BSA-PBS. After washing, the cells were treated with $2 \%$ p-formaldehyde for 30 min and washed with PBS before being analyzed by flow cytometry with a FACScan flow cytometer (model FACSCalibur, Becton Dickinson, San Jose, CA, USA) with the CellQuest analysis program (BD Biosciences, San Diego, CA, USA). Flow cytometry was performed using the appropriate single-stained samples for compensation setting. The number of cells expressing adhesion molecules was determined according to a forward light scatter/side light scatter gating combined with an FL-1 channel for immunostaining [20]. The mean fluorescence intensity (MFI) was measured by flow cytometry, and the MFI ratio (MFIr) was calculated by dividing the signal measured with the antibody $(\mathrm{Ab})$, anti-human VCAM-1 or anti-human ICAM-1, with papC, by the signal measured without peptide $(\mathrm{MFIr}=\mathrm{MFI} \mathrm{Ab}+$ papC/MFI Ab + without peptide average) in order to take into account eventual background differences [21].

RNA purification. All solutions used for RNA purification were treated with $0.1 \%(\mathrm{v} / \mathrm{v})$ diethyl pyrocarbonate (Sigma-Aldrich, USA) and all glassware was autoclaved at $240^{\circ} \mathrm{C}$ to remove RNAse traces. After a $12 \mathrm{~h}$ incubation period with $6.0 \mathrm{pM}$ papC in the presence or absence of TNF- $\alpha$, the 500,000 HMEC-1/flask were lysed using Trizol according to the manufacturer's instructions (LifeTechnologies Inc., Carlsbad, CA, USA). The lysate was centrifuged at $233 \mathrm{~g}$ for $20 \mathrm{~min}$ at $4^{\circ} \mathrm{C}$ with $200 \mu \mathrm{L}$ of chloroform (Sigma-Aldrich, USA). The supernatant was discarded and the pellet was suspended in $500 \mu \mathrm{L}$ of a $75 \%$ (v/v) ethanol/water solution. Samples were mixed and incubated at room temperature for 2-3 min, centrifuged at $200 \mathrm{~g}$ for $10 \mathrm{~min}$ at $4^{\circ} \mathrm{C}$, and the aqueous phase was collected. RNA was precipitated with equal volumes of isopropyl alcohol (Sigma-Aldrich, USA) at $56^{\circ} \mathrm{C}$ for $10 \mathrm{~min}$, shaken, and stored at $-70^{\circ} \mathrm{C}$. The integrity of the RNA was evaluated with $1 \%$ agarose gel electrophoresis. The amount of RNA was evaluated at $260 \mathrm{~nm}$ and the protein was determined at $280 \mathrm{~nm}$. The relationship between these two readings, approximately equal to 2 , indicated minimal protein contamination. Finally, $1 \%$ agarose gel electrophoresis was used to evaluate the RNA integrity in the sample.

RT-PCR analysis in TNF- $\alpha$-induced HMEC-1 expression of ICAM-1, VCAM-1, IL-8, and eNOS. We analyzed the products from target mRNA (ICAM-1, VCAM-1, IL-8, and eNOS), and one internal standard ( $\beta$-actin). Briefly, target RNA $(1 \mu \mathrm{g})$ was converted to cDNA by treatment with reverse transcriptase and oligo (dT) primer, as follows: 100 pM of oligo dT, $1 \mu \mathrm{L}$ of a mixture of deoxinucleotides (dNTPs) (Promega, Madison, WI, USA), and $10 \mu \mathrm{L}$ of sterile water (Promega) were mixed. The mixture was incubat- ed at $65^{\circ} \mathrm{C}$ for $5 \mathrm{~min}$ and at $4^{\circ} \mathrm{C}$ for $5 \mathrm{~min}$ before $2 \mu \mathrm{L}$ of $0.1 \mathrm{M}$ dithiothreitol (Promega) and $4 \mu \mathrm{L}$ of buffer $10 \times \mathrm{M} 190 \mathrm{~A}$ Promega $\left(10 \mathrm{mM}\right.$ Tris- $\mathrm{HCl}\left[\mathrm{pH} 9.0\right.$ at $\left.25^{\circ} \mathrm{C}\right] ; 50 \mathrm{mM} \mathrm{KCl}$; $0.1 \%$ Triton $\left.{ }^{\circledR} \mathrm{X}-100\right)$ were added to the mixture and then incubated at $37^{\circ} \mathrm{C}$ for $2 \mathrm{~min}$. Finally, $1 \mu \mathrm{L}$ of avian myeloblastosis virus (AMV) and $200 \mathrm{U} / \mu \mathrm{L}$ of reverse transcriptase (Promega) were incubated consecutively at $37^{\circ} \mathrm{C}$ for $50 \mathrm{~min}$, $70^{\circ} \mathrm{C}$ for $15 \mathrm{~min}$, and $4^{\circ} \mathrm{C}$ for $5 \mathrm{~min}$; for PCR amplification, $1 \mu \mathrm{g}$ of cDNA was used. Oligonucleotides were synthesized in the Laboratory of Cellular Biology, National Institute of Cardiology Ignacio Chavez (Mexico) with an automatic synthesizer (Applied Biosystems 392/394 DNA synthesizers, Carlsbad, CA, USA): ICAM-1 sense 5'-TAT GGC AAC GAC TCC TTC T-3', anti-sense 5'-CAT TCA GCG TCA CCT TGG-3'; for VCAM-1 sense 5'-ATG ACA TGC TTG ACC AGG-3', anti-sense 5'-GTG TCT CCT TCT TTG ACA CT-3' [22]; for IL-8 sense 5'-CTC TCT TGG CAG CCT TCC TGA-3', anti-sense 5-CCC TCT GCA CCC AGT TTT CCT T-3' [23]; for eNOS sense 5'-CCA GCT AGC CAA AGT CAC CAT-3' and anti-sense 5'-GTCTCGGAG CCA TAC AGG ATT-3' [24]. Amplification was performed in a Px2 Thermal Cycler (Thermo Electron Corporation, Lexington, KY, USA). We used $\beta$-actin as an internal control; the sense primer was 5'-TAC-ATG-GCT-GGG-GTG-TTG-AA-3' and the sequence of the antisense primer was 5'-TCC AAG GGT CCG CTG CAG GTC-3', generating a 230-pb product. We used $0.5 \mu \mathrm{L}$ of Taq DNA polymerase $(5 \mathrm{U} / \mu \mathrm{L})$ (Altaenzymes, St. Albert, Alberta, Canada). PCR conditions were as follows: ICAM-1: denaturation $95^{\circ} \mathrm{C}, 5 \mathrm{~min}$; alignment $57.1^{\circ} \mathrm{C}$, $1 \mathrm{~min}$; elongation $72^{\circ} \mathrm{C}, 45 \mathrm{~s}$. VCAM-1: denaturation $94^{\circ} \mathrm{C}$, $5 \mathrm{~min}$; alignment $56^{\circ} \mathrm{C}, 1 \mathrm{~min}$; elongation $72^{\circ} \mathrm{C}, 1 \mathrm{~min}$; eNOS: denaturation $94^{\circ} \mathrm{C}, 45 \mathrm{~s}$; alignment $55^{\circ} \mathrm{C}, 1 \mathrm{~min}$, elongation $72^{\circ} \mathrm{C}, 2 \mathrm{~min} ; \beta$-actin: denaturation $94^{\circ} \mathrm{C}, 45 \mathrm{~s}$; alignment $60^{\circ} \mathrm{C}$, $45 \mathrm{~s}$; elongation $72^{\circ} \mathrm{C}, 2 \mathrm{~min}$. We performed 35 amplification cycles for all molecules. DNA electrophoresis was performed in $2 \%$ agarose gel containing $0.5 \mathrm{mg} / \mathrm{mL}$ ethidium bromide (Sigma-Aldrich, USA). Gels were visualized and photographed with a Chemi-Doc image analyzer (Bio-Rad, Hercules, CA, USA). To compare band intensities, the gels were scanned and analyzed with VisionWorksLS Analysis Software (UVP, Upland, CA, USA). Analyses were performed in triplicate.

Cell adhesion assays. Jurkat cells ( $\mathrm{CD} 3^{+}$lymphoblasts) were from the Laboratory of Cellular Biology, National Institute of Cardiology Ignacio Chavez (Mexico). Jurkat cells were cultured in RPMI-1640 medium, $10 \%$ fetal calf serum, $10 \mathrm{mM} \mathrm{HEPES}$, and $2 \mathrm{mML}$-glutamine (Sigma-Aldrich, USA) at $37^{\circ} \mathrm{C}$ in $7 \% \mathrm{CO}_{2}$. Jurkat cells $\left(1.5 \times 10^{6}\right.$ cells $\left./ \mathrm{mL}\right)$ labeled with BCECF-AM (Molecular Probes, Eugene, OR, USA) in HEPES buffer ( $\mathrm{pH}$ 7.2; Sigma-Aldrich, USA) were used to identify adherent cells, according to the manufacturer's instructions [25]. Adhesion assays were carried out in 24-well tissue culture plates (Nalgene Nunc International, 
Rochester, NY, USA) seeded with $1 \times 10^{5}$ endothelial cells cultured for $24 \mathrm{~h}$ to allow the formation of monolayers, before adding BCECF-AM-labeled Jurkat cells $\left(3 \times 10^{5}\right)$. The cells were allowed to interact with HMEC-1 for $1 \mathrm{~h}$; nonadherent cells were removed by gently washing with HEPES buffer ( $\mathrm{pH}$ 7.2). Adhesion of Jurkat cells to HMEC was determined by counting the number of Jurkat cells in five to seven randomly selected fields $(\times 20)$, with an epi-fluorescence inverted microscope (Axiovert 200, Zeiss, Göttingen, Germany). The effects of TNF- $\alpha$, papC, and control peptide on cellular adhesion were determined by adding TNF- $\alpha$ $(5 \mathrm{ng} / \mathrm{mL})$, different concentrations of papC or the control peptide (2-6 pM), or papC simultaneously with TNF- $\alpha$ $(5 \mathrm{ng} / \mathrm{mL})$ to the cell monolayers, $12 \mathrm{~h}$ before adding the Jurkat cells. The experiments were performed ten times and the results were obtained by comparing the effect of TNF- $\alpha$ on cellular adhesion in cells treated with papC or control peptides, and reported as a percentage \pm standard deviation (SD) of the mean of cells that adhered to at least two Jurkat cells.

Statistical analysis. Data was expressed as the mean \pm SD. One-way ANOVA was used to analyze the effect of papC on the expression of ICAM-1 and VCAM-1 in HMEC-1; results with $\mathrm{p}$ values $<0.05$ were considered significant. Dunn's multiple comparisons post-test was used to compare adhesion molecules among different groups. The calculations were performed with GraphPad Prism version 3.00 for Windows (GraphPad Software, San Diego, CA, USA; www.graphpad.com).

\section{Results}

\section{VCAM-1 and ICAM-1 expression in the presence of papC}

After HMEC-1 was stimulated with $5 \mathrm{ng} / \mathrm{mL} \mathrm{TNF-} \alpha$ for $6 \mathrm{~h}$, the expression of ICAM-1 was increased (MFI = $=300.34)$, compared to HMEC-1 control cells not stimulated with TNF- $\alpha(\mathrm{MFI}=158.86)$. However, there was no significant difference between cells also treated with $6.0 \mathrm{pM}$ papC $(\mathrm{MFIr}=0.99)$ or a control peptide alone $(\mathrm{MFIr}=1.00)$ after incubation for $6-$ $-20 \mathrm{~h}$. The expression of ICAM-1 was lower at $12 \mathrm{~h}$ $(\mathrm{MFIr}=0.73)$ versus $20 \mathrm{~h}(\mathrm{MFIr}=0.99)$. Twelve hours after the addition of $6.0 \mathrm{pM}$ papC and TNF- $\alpha$, ICAM-1 expression in HMEC-1 cells was significantly diminished (Figure 1A).

After stimulation of HMEC- 1 with $5 \mathrm{ng} / \mathrm{mL} \mathrm{TNF-} \alpha$ for $6 \mathrm{~h}$, the expression of VCAM-1 was increased $(\mathrm{MFI}=400.97)$, compared to control cells not stimulated with TNF- $\alpha$ (MFI = 200.10).

Similarly to ICAM-1, papC alone showed no effect on VCAM-1 expression in HMEC-1 (MFIr = 0.98), after exposure for 6-20 h (Figure 1B), which was comparable to control peptide treatment (MFIr 0.99) at
$6 \mathrm{~h}$ and $12 \mathrm{~h}$ (data not shown). After TNF- $\alpha$ exposure with $6.0 \mathrm{pM}$ papC for $12 \mathrm{~h}, \mathrm{VCAM}-1$ expression significantly decreased, giving a MFIr of less than 0.2.

\section{ICAM-1 and VCAM-1 mRNA expression}

TNF- $\alpha$ was considered to be $100 \%$ expressed in stimulated cells, compared to nonstimulated HMEC-1 (Figure 2). ICAM-1 and VCAM-1 mRNA expression increased in HMEC-1 after stimulation with $5 \mathrm{ng} / \mathrm{mL}$ TNF- $\alpha$ for $12 \mathrm{~h}$. In contrast, the control peptide did
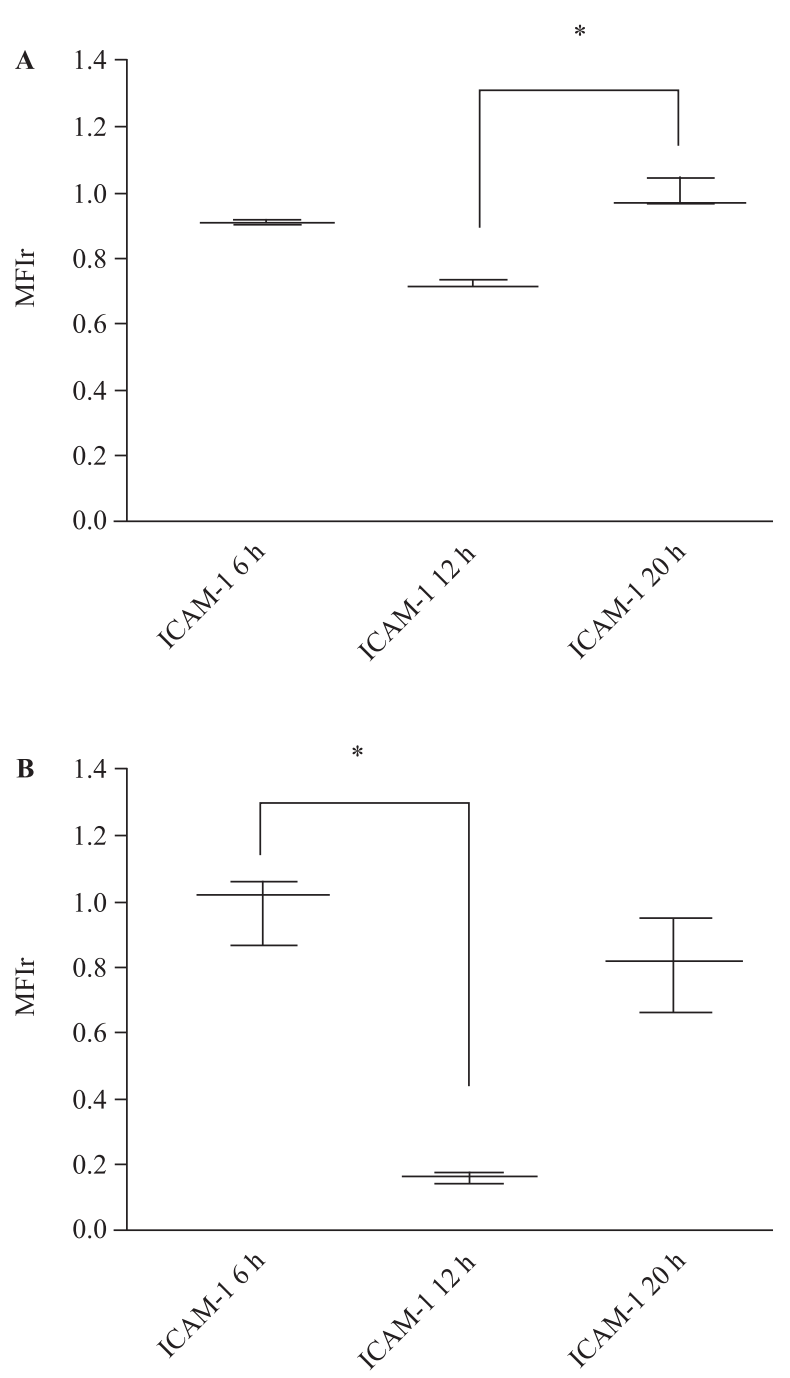

Figure 1. Expression of ICAM-1 and VCAM-1 in HMEC-1 cells with papC in the presence of TNF- $\alpha$. (A) The expression of ICAM-1 (FITC) and (B) VCAM-1 (PE) in HMEC-1, induced by TNF- $\alpha$ in the presence of papC, was measured. In each determination, 5,000 cells were evaluated. The mean fluorescence intensity (MFI) was measured using a FACScan flow cytometer. The MFI ratio (MFIr) was calculated by dividing the signal with the papC antibody by the signal measured without peptide. The Kruskal-Wallis Test with Dunn's Multiple Comparison Test was used to determine significance; ${ }^{*} \mathrm{p}<0.05$ 


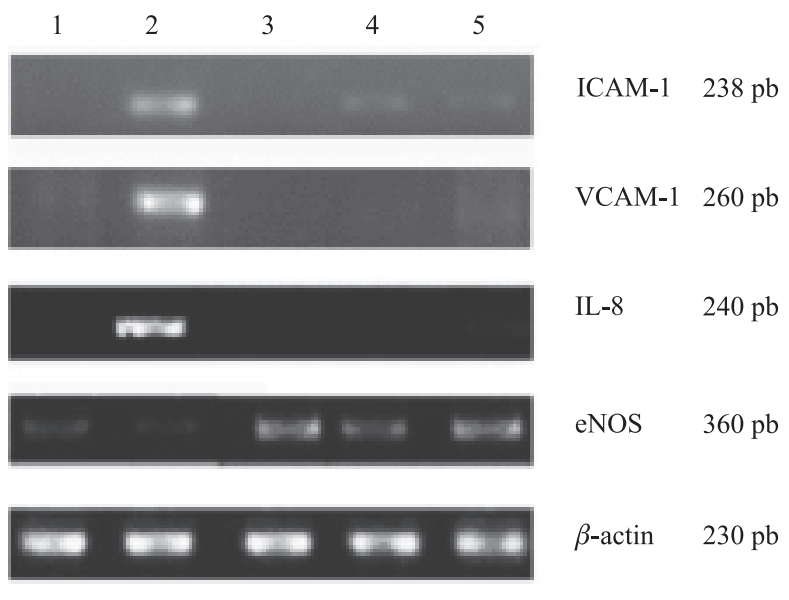

Figure 2. The effect of TNF- $\alpha$ and papC on the expression of ICAM-1, VCAM-1, IL-8, and eNOS mRNA in HMEC-1 cells. Lane 1: control assays with nonstimulated HMEC-1. Lane 2: HMEC-1 cells treated with $5 \mathrm{ng} / \mathrm{mL}$ TNF- $\alpha$. Lane 3: HMEC- 1 treated with $2 \mathrm{pM}$ papC plus $5 \mathrm{ng} / \mathrm{mL}$ TNF- $\alpha$. Lane 4: HMEC-1 treated with 4 pM papC plus $5 \mathrm{ng} / \mathrm{mL}$ TNF- $\alpha$. Lane 5: HMEC-1 treated with $6 \mathrm{pM}$ papC plus $5 \mathrm{ng} / \mathrm{mL}$ TNF- $\alpha$. $\beta$-actin mRNA was used as an amplification control. Results are representative samples from three replicates

not induce changes in ICAM-1 and VCAM-1 mRNA expression (data not shown).

The expression of ICAM-1 mRNA was between $20 \%$ and $40 \%$ less when the cells were incubated with $2 \mathrm{pM}$, $4 \mathrm{pM}$, or $6 \mathrm{pM}$ papC and TNF- $\alpha$, compared to TNF- $\alpha$ stimulation alone. Similarly, VCAM-1 mRNA expression was approximately $20 \%$ less when cells were simultaneously incubated with papC at $2 \mathrm{pM}, 4 \mathrm{pM}$, or $6 \mathrm{pM}$ and TNF- $\alpha$, compared to TNF- $\alpha$ stimulation alone. However, a dose-dependent relationship was not observed.

\section{IL-8 mRNA expression}

IL-8 mRNA expression was higher in cells stimulated with TNF- $\alpha$ after $12 \mathrm{~h}$ of incubation, compared to nonstimulated cells, and that expression was considered as $100 \%$. In contrast, control peptide did not induce changes in IL-8 mRNA expression (data not shown). HMEC-1 does not express IL-8 constitutively; therefore, the effect of papC on IL-8 expression was determined after exposure to $5 \mathrm{ng} / \mathrm{mL}$ TNF- $\alpha$. When cells were simultaneously incubated with 2-6 pM papC and TNF- $\alpha$, the IL- 8 mRNA expression was less than 5\%, compared to HMEC-1 stimulated with only $5 \mathrm{ng} / \mathrm{mL}$ TNF- $\alpha$ (Figure 2 ).

\section{eNOS mRNA expression}

Expression of eNOS mRNA in HMEC-1 decreased by less than $5 \%$ after treatment with $5 \mathrm{ng} / \mathrm{mL} \mathrm{TNF}-\alpha$, compared to nontreated cells. In contrast, control peptide did not induce changes in eNOS mRNA expression (data not shown). The expression of eNOS mRNA increased by more than $30 \%$ in HMEC- 1 cells stimulated with TNF- $\alpha$ and in the presence of $2 \mathrm{pM}$, $4 \mathrm{pM}$, and $6 \mathrm{pM}$ of papC (Figure 2).

\section{Cellular adhesion in the presence of papC}

HMEC-1 showed that basal adhesion to Jurkat cells was less than $2 \%$, whereas maximal adhesion $(85 \pm 5 \%)$ was obtained with $5 \mathrm{ng} / \mathrm{mL}$ TNF- $\alpha$. Basal adhesion to Jurkat cells was not affected by papC. In addition, adhesion to Jurkat cells was not significantly affected by the presence of the control peptide. Also, the control peptide did not exert a significant effect on cell adhesion induced by TNF- $\alpha$ (data not shown). In a TNF- $\alpha$ activated HMEC-1 cell layer, significant inhibition of Jurkat adhesion to HMEC-1 cells in the presence of papC was observed. Specifically, $36 \pm 5 \%, 34 \pm$ $3 \%$, and $18 \pm 4 \%$ of Jurkat adhesion was achieved with $2 \mathrm{pM}, 4 \mathrm{pM}$, and $6 \mathrm{pM}$ papC, respectively (Figure 3).

\section{Discussion}

Protein $\mathrm{C}$ activation peptide (papC) is released from protein $\mathrm{C}$ by thrombin, generating activated protein $\mathrm{C}$ (APC). It has been shown that APC has cytoprotective effects via inhibition of apoptosis and inflammation in humans and animals [26]; in addition, it is able to inhibit cytokine signaling and the expression of cell-surface adhesion molecules. APC inhibits neutrophil adhesion to and migration from extracellular matrix proteins by binding to the $\beta_{1}$ and $\beta_{3}$ integrins of neutrophils [27]. It has been suggested that papC could alter the inflammatory process by inhibiting thrombin-induced platelet aggregation [28]. In this research, we showed that papC exerts anti-inflammatory effects on the endothelial cell line HMEC-1 by inhibiting the expression of adhesion molecules ICAM-1, VCAM-1, and IL-8.

In this investigation, we evaluated the effect of papC in HMEC-1 because this cell line preserves the morphology, phenotype, and several characteristics of normal microvascular endothelial cells when activated with TNF- $\alpha$ [29]. ICAM- 1 is a constitutive molecule of HMEC-1 and its expression increases after appropriate stimulation. After incubating HMEC-1 with $5 \mathrm{ng} / \mathrm{mL}$ TNF- $\alpha$ plus $6.0 \mathrm{pM}$ papC, the expression of ICAM-1 mRNA decreased steadily compared to cells that were activated with TNF- $\alpha$ alone. ICAM-1 participates as a receptor for LFA- 1 , a $\beta_{2}$-integrin expressed on neutrophils, monocytes, lymphocytes, and natural killer cells, a fact that may explain the inhibition of Jurkat cell adhesion in the presence of papC. The adhesion of Jurkat cells to HMEC- 1 shows a dose-dependent effect, since higher doses of papC 

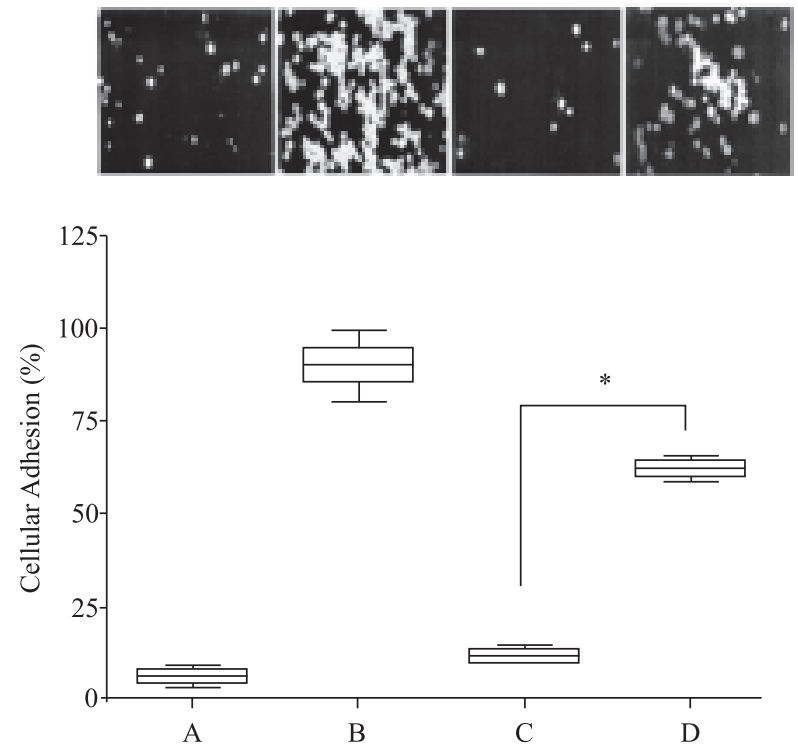

Figure 3. Adhesion assays were carried out with endothelial cell monolayers $\left(1 \times 10^{5}\right)$, before adding $3 \times 10^{5}$ BCECFlabeled Jurkat cells. Adhesion of HMEC to Jurkat cells was quantified by counting the adhered cells in five to seven randomly selected fields $(20 \times)$. The effect of $5 \mathrm{ng} /$ $/ \mathrm{mL}$ TNF- $\alpha$, papC, and control peptide was determined by incubating $5 \mathrm{ng} / \mathrm{mL}$ TNF- $\alpha$ alone or with different concentrations of papC or the control peptide (from 2 to $6 \mathrm{pM}$ ) to the cell monolayers for $12 \mathrm{~h}$, which was the optimal time for the highest expression of adhesion molecules, before Jurkat cells were added. The experiments were performed ten times and the results were obtained by comparing the effect of TNF- $\alpha$ to cells treated with papC or control peptides, and reported as percentage \pm SE of cells that adhered to at least two Jurkat cells. (A) Basal, (B) $5 \mathrm{ng} / \mathrm{mL} \mathrm{TNF-} \alpha$, (C) 6 pM papC plus $5 \mathrm{ng} / \mathrm{mL}$ TNF- $\alpha$, (D) $6 \mathrm{pM}$ control peptide plus $5 \mathrm{ng} / \mathrm{mL}$ TNF- $\alpha ;{ }^{*} \mathrm{p}<0.05$

resulted in a higher inhibition of adhesion. The inhibition observed in the adhesion test correlated with the inhibition observed in the expression of ICAM-1 and VCAM-1, which are involved in the adhesion of endothelial cells during the inflammatory process.

VCAM-1 is an inducible membrane receptor that interacts with Very Late Antigen-4 (VLA-4) and it is expressed only after endothelial cell activation. In addition, APC down-regulates VCAM-1 transcription [28]. The papC sequence lacks the RGD sequence, a key motif of APC for its interaction with neutrophil integrins. However, it is interesting to note that papC as well as APC induced inhibition of VCAM- 1 at $12 \mathrm{~h}$, thus suggesting a regulatory effect of this peptide on leukocyte adhesion by integrin-independent mechanisms [23]. It has been shown that activated APC ameliorates the TNF- $\alpha$-induced inflammatory response of endothelium via the endothelial APC receptor. Hence, the possibility that the endothelium has specific receptors for papC should not be ruled out [30]. The pap $C$ in vascular endothelium as well as in platelets has shown dose-dependent effects, suggesting that specific receptors for papC could be present in different cells [2].

Neutrophil recruitment across the endothelium is mainly due to concentration gradients of IL-8, an interleukin synthesized by the endothelium in response to inflammatory signals such as TNF- $\alpha$ [31]. TNF- $\alpha$ induces IL-8 expression in both HUVEC and HMEC-1 [29]. The expression of IL- 8 by the HMEC- 1 cell line induced by TNF- $\alpha$ decreased in the presence of papC. In addition, endothelial cells constitutively express eNOS, which can be down-regulated by cytokines such as TNF- $\alpha$ [32]; and down-regulation of eNOS is a crucial mechanism that results in endothelial dysfunction [33].

Thus, our experiments suggest that papC exerts anti-inflammatory effects on endothelial cells by promoting inhibition of cytokine signaling and adhesion molecule expression. The adhesion between Jurkat cells and HMEC-1 was reduced in the presence of papC compared to the control peptide with TNF- $\alpha$, suggesting that papC is able to modulate the expression of molecules involved in inflammatory and cellcell adhesion processes. The intrinsic signaling networks of the coagulation pathways have recently emerged as relevant determinants for survival in sepsis and systemic inflammatory response syndromes $[34,35]$. Therefore, the release of papC after APC cleavage could represent an alternative to regulate the pro-inflammatory process.

\section{Acknowledgments}

The authors would like to acknowledge Diana MatiasPérez for her excellent technical assistance. The authors want to extend special thanks to Jan Moreno and Consuelo Arteaga Murphy for their editorial assistance.

\section{References}

1. Riewald M, Schuepbach RA. Protective signaling pathways of activated protein C in endothelial cells. Arterioscler Thromb Vasc Biol. 2008;28:1-3.

2. Martínez-Cruz R, Canseco M del S, Lopez-Martínez J et al. Interaction of the protein $\mathrm{C}$ activation peptide with platelets. Prep Biochem Biotechnol. 2007;37:139-147.

3. Gruber A, Marzec UM, Bush L et al. Relative antithrombotic and antihemostatic effects of protein $\mathrm{C}$ activator versus low-molecular-weight heparin in primates. Blood. 2007;109:3733-3740.

4. O'Brien LA, Gupta A, Grinnell BW. Activated protein C and sepsis. Front Biosci. 2006;11:676-698.

5. Riewald M, Ruf W. Protease-activated receptor-1 signaling by activated protein $\mathrm{C}$ in cytokine-perturbed endothelial cells is distinct from thrombin signaling. J Biol Chem. 2005;280:19808-19814. 
6. Feistritzer C, Schuepbach RA, Mosnier LO et al. Protective signaling by activated protein $\mathrm{C}$ is mechanistically linked to protein C activation on endothelial cells. J Biol Chem. 2006;281:20077-20084.

7. Schuepbach RA, Riewald M. Coagulation factor Xa cleaves protease-activated receptor-1 and mediates signalling dependent on binding to the endothelial protein $\mathrm{C}$ receptor. J Thromb Haemost. 2010;8:379-388.

8. Laterre PF, Levy H, Clermont $\mathrm{G}$ et al. Hospital mortality and resource use in subgroups of the recombinant human activated protein $\mathrm{C}$ worldwide evaluation in severe sepsis (PROWESS) trial. Crit Care Med. 2004;32:2207-2218.

9. Schmidt-Supprian M, Murphy C, While B et al. Activated protein $\mathrm{C}$ inhibits tumor necrosis factor and macrophage migration inhibitory factor production in monocytes. Eur Cytokine Netw. 2000;11:407-413.

10. Murakami K, Okajima K, Uchiba M et al. Activated protein C attenuates endotoxin-induced pulmonary vascular injury by inhibiting activated leukocytes in rats. Blood. 1996;87:642-647.

11. Panés J, Perry MA, Anderson DC et al. Regional differences in constitutive and induced ICAM-1 expression in vivo. Am J Physiol. 1995;269:H1955-H1964.

12. Van Seventer GA, Shimizu Y, Horgan KJ, Shaw S. The LFA-1 ligand ICAM-1 provides an important costimulatory signal for $\mathrm{T}$ cell receptor-mediated activation of resting $\mathrm{T}$ cells. J Immunol. 1990;144:4579-4586.

13. Elices MJ, Osborn L, Takada Y et al. VCAM-1 on activated endothelium interacts with the leukocyte integrin VLA-4 at a site distinct from the VLA-4/fibronectin binding site. Cell. 1990;60:577-584.

14. Viemann D, Goebeler M, Schmid S et al. TNF-alpha induces distinct gene expression programs in microvascular and macrovascular human endothelial cells. J Leukoc Biol. 2006;80:174-185.

15. Remick DG, Villarete L. Regulation of cytokine gene expression by reactive oxygen and reactive nitrogen intermediates. J Leukoc Biol. 1996;59:471-475.

16. Joyce DE, Gelbert L, Ciaccia A, Dehoff B, Grinnell BW. Gene expression profile of antithrombotic protein $\mathrm{C}$ defines new mechanisms modulating inflammation and apoptosis. J Biol Chem. 2001;276:11199-11203.

17. Franscini N, Bachli EB, Blau N, Leikauf MS, Schaffner A, Schoedon G. Gene expression profiling of inflamed human endothelial cells and influence of activated protein C. Circulation. 2004;110:2903-2909.

18. Bordo D, Argos P. Suggestions for "safe" residue substitutions in site-directed mutagenesis. J Mol Biol. 1991;217:721-729 .

19. Karplus PA. Hydrophobicity regained. Protein Sci.1997;6:1302-1307.

20. Shimizu T, Oda M, Azuma T. Estimation of the relative affinity of B cell receptor by flow cytometry. J Immunol Methods. 2003;276:33-44.

21. Decker P, Kötter I, Klein R, Berner B, Rammensee HG. Monocyte-derived dendritic cells over-express CD86 in patients with systemic lupus erythematosus. Rheumatology (Oxford). 2006;45:1087-1095.
22. Kaplanski G, Marin V, Fabrigoule M et al. Thrombin-activated human endothelial cells support monocyte adhesion in vitro following expression of intercellular adhesion molecule1 (ICAM-1; CD54) and vascular cell adhesion molecule-1 (VCAM-1; CD106). Blood. 1998;92:1259-1267.

23. Loboda A, Jazwa B, Wegiel A, Jozkowicz A, Dulak J. Heme oxygenase-1-dependent and independent regulation of angiogenic genes expression: effect of cobalt protoporphyrin and cobalt chloride on VEGF and IL-8 synthesis in human microvascular endothelial cells. Cell Mol Biol (Noisy-le-grand). 2005;51:347-355.

24. Alvarado-Vasquez N, Zapata E, Alc $\alpha$ zar-Leyva S, Massó F, Montańo LF. Reduced NO synthesis and eNOS mRNA expression in endothelial cells from newborns with a strong family history of type 2 diabetes. Diabetes Metab Res Rev. 2007;23:559-566.

25. Aubry JP, Shields JG, Jansen KU, Bonnefoy JY. A multiparameter flow cytometric method to study surface molecules involved in interactions between subpopulations of cells. J Immunol Methods. 1993;159:161-171.

26. Loubele ST, Spek CA, Leenders $P$ et al. Activated protein C protects against myocardial ischemia/reperfusion injury via inhibition of apoptosis and inflammation. Arterioscler Thromb Vasc Biol. 2009;29:1087-1092.

27. Elphick GF, Sarangi PP, Hyun YM et al. Recombinant human activated protein $\mathrm{C}$ inhibits integrin-mediated neutrophil migration. Blood. 2009;113:4078-4085.

28. De Caterina R, Libby P, Peng HB et al. Nitric oxide decreases cytokine-induced endothelial activation: nitric oxide selectively reduces endothelial expression of adhesion molecules and proin?ammatory cytokines. J Clin Invest. 1995;96:60-68 .

29. Ades EW, Candal FJ, Swerlick RA, George VG, Summers S, Bosse DC, Lawley TJ. HMEC-1: establishment of an immortalized human microvascular endothelial cell line. $J$ Invest Dermatol. 1992;99:683-690.

30. Chen Y, Peng J, Liu X, Wu J, Li R, Zheng X. Activated protein $\mathrm{C}$ ameliorates TNF-alpha-induced inflammatory response of endothelium via the endothelial protein $\mathrm{C}$ receptor. Sheng Wu Yi Xue Gong Cheng Xue Za Zhi. 2009;26:625-630 .

31. Huber AR, Kunkel SL, Todd RF $3^{\text {rd }}$, Weiss SJ. Regulation of transendothelial neutrophil migration by endogenous interleukin-8. Science. 1991;254:99-102.

32. Lai PF, Mohamed F, Monge JC, Stewart DJ. Down-regulation of eNOS mRNA expression by TNF-alpha: identification and functional characterization of RNA-protein interactions in the 3'UTR. Cardiovasc Res. 2003;59:160-168.

33. Jaimes EA, del Castillo D, Rutherford MS, Raij L. Countervailing influence of tumor necrosis factor-alpha and nitric oxide in endotoxemia. J Am Soc Nephro. 2001;12:1204-1210.

34. He HY, Wang C, Pang BS. Effects of activated protein C on coagulation and fibrinolysis in rabbits with endotoxin induced acute lung injury. Chin Med J (Engl). 2008;121:2561-2565.

35. Ruf W, Furlan-Freguia C, Niessen F. Vascular and dendritic cell coagulation signaling in sepsis progression. J Thromb Haemost. 2009;7 Suppl 1:118-121.

Submitted: 30 April, 2011

Accepted after reviews: 20 February, 2012 